Author: Lea Locke, Michelle

Article Title: Wirrawi Bubuwul - Aboriginal Women Strong

Journal Title: Australian Journal of Education

Date: 09 Nov 2018

Volume 62

Issue 3

Pages: $299-310$

Copyright (C) 2019 Sage Publications

Reprinted by permission of SAGE Publications.

online version available on the SAGE Journals website

$\underline{10.1177 / 0004944118799483}$ 
Locke ML. (2018) Wirrawi Bubuwul-Aboriginal Women Strong. Australian journal of education 62: 299-310.

\title{
WIRRAWI BUBUWUL - ABORIGINAL WOMEN STRONG
}

\begin{abstract}
The scholastic success of Bolongaia (Maria Lock), at the Parramatta Native Institution in 1819, arguably positions her as an academic giant. Bolongaia's exam results challenged the opinions of the day when she 'bore away the chief prize' (Sydney Gazette 1819, p.2). Bolongaia's academic success was based purely on her acquisition of western based knowledges and values (Battiste 2005; Martin 2003). In contrast, I was awarded a Masters of Indigenous Education in 2016. This academic achievement draws attention to a significant change in the positioning of Aboriginal Knowledges in the academy. This paper is a letter to my ancestral grandmother, Bolongaia to tell her about the Aboriginal women who have challenged the status quo of western based educational frameworks and research paradigms. This paper honours the Aboriginal women who have paved a way for Aboriginal knowledges in mainstream educational institutions in ways that Bolongaia was unable to experience and perhaps even imagine in her lifetime.
\end{abstract}

\section{Introduction}

Dear Grandmother Bolongaia, I write this letter to you in response to this year's NAIDOC Theme, 'Because of Her We Can'. I want to firstly thank you for leaving a legacy that enables us, Dharug mob to stand proud. I want also to tell you about some of the women over the last three generations that continue to challenge dominant views about who we are and what it means to be an Aboriginal person living in Australian today. This year - 2018 - marks the $201^{\text {st }}$ year since your incarceration in the Native Institution and although your story is not shared or taught in our schools, your grandchildren, eight generations later, know who you are and how your actions have shaped the opportunities they themselves have today. As one of your many descendants, I wish to thank you for your strength, resilience, wisdom and spirit that sees me, raising my voice with our people about our Ways of Knowing, Being and Doing. 
Grandmother Bolongaia, I want you to know that your Dharug descendants are walking many paths and fill many roles in society today. Together we keep alive the spirit, knowledge and culture of our Country and peoples and I want you to know that it is your strength and actions that helped to lay the foundations of the path we now walk. In honouring cultural protocols, I identify my position and place in relation to you, Bolongaia. My connection to Dharug Country is through my maternal Grandmother Win, Winifred Harkins nee Locke, I am a seventh generation descendent of Yarramundi, your father, Kuradji (chief) of the Boorooberongal clan of the Dharug Nation. I acknowledge my responsibility and accountability to my relations and ancestors to tell the truth and to advocate their wisdom, strength and resilience.

Diagram 1: Family Line with Maternal Grandmother

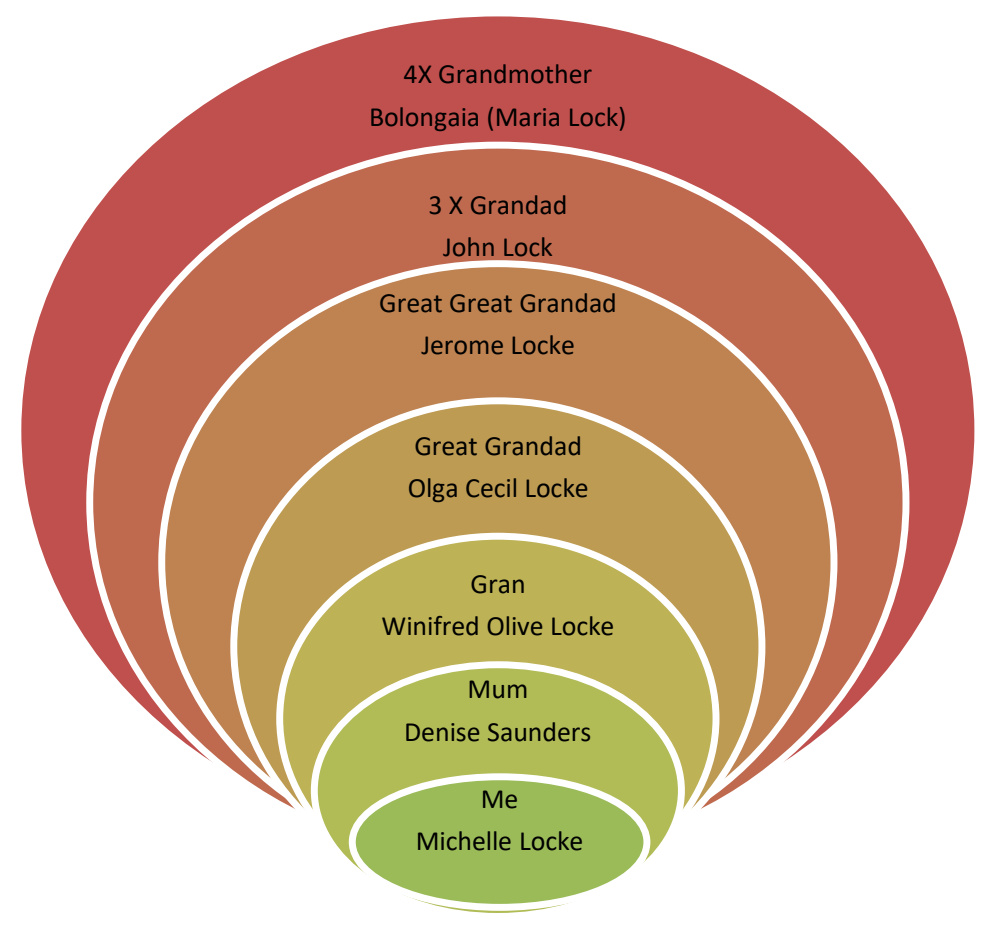

\section{Prior to the Academy}

Dear Grandmother Bolongaia,

The main theme of this paper that I address to you, has a focus on the achievements and influence of Aboriginal and Torres Strait Islander women in the academy. However, from the outset, I wish to acknowledge and proffer my gratitude to the many women who for a variety 
of reasons, have not been able or have not chosen to engage in academic careers but have enabled myself and others to do exactly that. These women, I speak of are our mothers, sisters, aunts and grandmothers whose Aboriginal and Torres Strait Islander voices were silenced by colonisation, resulting in the absence of Indigenous perspectives and knowledges in mainstream society and the academy for many generations (Battiste 2005; Smith 2012).

To begin, I wish to share with you a story of my maternal Grandmother Win, (Winfred Olive Harkins - nee Locke). Born in 1921, she was an only child and, was not told about her connection to this Country and did not learn this truth until she was in her eighties. On learning about her father's identity and her connection to Dharug Country, my Grandmother Win cried, saying, 'there are things in my childhood that make sense to me now'. I know that in your time Grandmother Bolongaia, being Aboriginal attracted shame and disrespect and that your experience of western education was in the form of an experimental school known as the Parramatta Native Institute. It was established in 1814 by Governor Macquarie with the specific intention of 'civilising' Aboriginal children through the provision of western knowledge and the indoctrination of Christianity (Christie 1994; Cruickshank 2008). Despite your documented success in this institution (Sydney Gazette 1819), Aboriginal children were excluded from mainstream schools by legislation that identified Aboriginal children as uneducable. In 1848, in New South Wales it was deemed, 'impracticable to provide any form of educational facilities for the children of the Blacks' (Parbury 2011, p.133). This type of legislation contributed to stereotypical attitudes surrounding Aboriginal intellect and social acuity.

The exclusion of Aboriginal children in mainstream schools was compounded by the exclusion of Aboriginal Ways of Knowing in mainstream education curriculums (Morgan 2006; Parbury 2011). Under the guise of 'protection', many Aboriginal and Torres Strait Islander children were forcibly removed from their families and communities (Wilkie 1997). This was a deliberate and an effective act that severed critical Aboriginal and Torres Strait Islander links to Country. Your children, Grandmother Bolongaia, and others like them were expected to conform to the values and expectations of non-Aboriginal mainstream society at the cost of Indigenous Ways of Knowing, Being and Doing (Battiste 2005; MoretonRobinson 2009). In an attempt, to protect children from abduction, many Aboriginal parents kept silent about their Aboriginal identity, and worse still, many Aboriginal parents stopped speaking Aboriginal languages and sharing cultural practices with their children and grandchildren. So, as a result of segregation and silencing, many Aboriginal children, such as 
Grandmother Win, grew up not knowing who they were and/or which Aboriginal Country they were connected to.

My beautiful Grandmother Win was ninety-four years young when she left her physical body in April 2016. On many occasions before her passing she expressed much pride in learning about her father's heritage and openly expressed her joy in meeting family she did not know she had. I will never stop missing her and I feel responsibility to use my privilege of participating in the academy to speak the words she could not say in her youth. Grandmother Win's story gives me strength and determination to participate in the academy to ensure the life she lived does not go untold or unnoticed.

Grandmother Bolongaia, it is a true story that I would not be in the position I am now without the support and love of my mother, Denise and sister, Julie. Their knowledge, wisdom and life experiences have guided, supported and strengthened my own learning and sense of belonging. Their faith in me never wanes and their sense of humour and blatant honesty keeps me real. Together we share, celebrate, and grieve many experiences and events and it is for this reason that I know my achievements to attend and succeed in the academy are equally their achievements.

Grandmother Bolongaia, I attest to the wealth of cultural knowledge, wisdom and commitment my Dharug Sisters and Aunties hold for family and community. They remind me that education is not confined to the academy and that responsibility, accountability and reciprocity to family and community are the core of all teaching and learning. To me, they are warrior women (Bunda 2018) as they speak the truths of Dharug experiences and knowledges to audiences that are often misguided about the reality of Aboriginal lives past and present (Behrendt 2016; Heiss 2012). Our Dharug and other Aboriginal Aunties and Sisters talk and work to raise Aboriginal voices and influence political agendas so that our children can be proud and engage with Aboriginal Ways of Knowing and Being well into the future. 


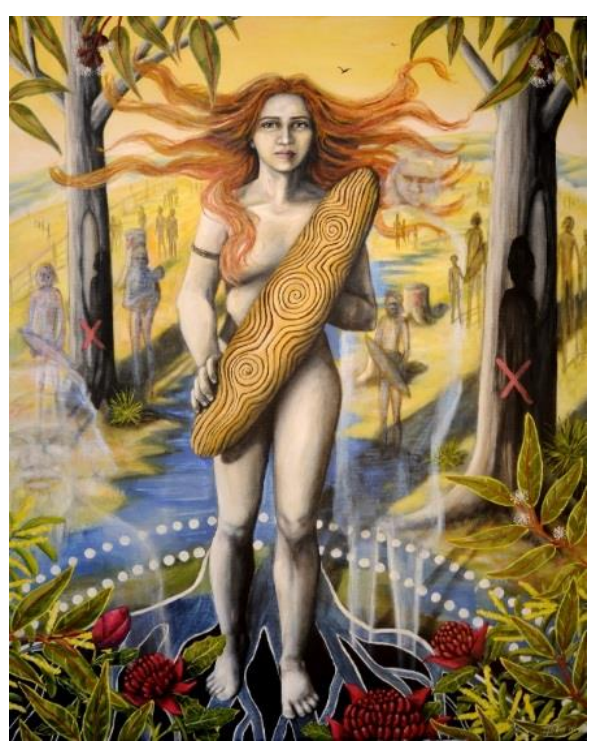

This painting 'Defending Country' by Leanne Tobin was awarded the 2011 Parliament of New South Wales Aboriginal Art Prize. It is her depiction and tribute to you, Grandmother Bolongaia. In an interview, Leanne explained,

'it's saying we're still here, we've changed colour but our ancestry's here, it's connected to here, we haven't gone away, we're not going away, and ... we're going to defend country no matter what'(Torpey 2013).

Finally, Grandmother Bolongaia, I acknowledge the women who walk with you in spirit, my Grandmother Win, my little sister, Dannie, and my cousin, Aunty Chris Burke. Each one has shaped the woman I am today and my need to honour the lives they lived, their joy, sadness, triumphs and challenges drive me to stay focussed, honest and determined to create change if only in my little section of the world.

\section{The Academy and Beyond}

Dear Grandmother Bolongaia,

It is exciting to tell you Grandmother Bolongaia, that in 2018 Aboriginal and Torres Strait Islander peoples fulfil many roles in Australian society and despite these roles being embedded in a dominant western system (Behrendt 1995; Hogarth 2017; Page 2017; Smith 2012), Aboriginal Ways of Knowing are evident in many arenas. Some examples of this include, the Arts where Aboriginal perspectives of Australian history, politics and society are given voice thru art, dance, music and film. In the academy female Indigenous scholars such as Kovach (2009), Martin (2008), Moreton-Robinson (2009) and Smith (2012) are developing, advocating and implementing Indigenous research methods that aim to dismantle the short-sighted views of western research paradigms and methodologies that serve to categorise and devalue Indigenous Ways of Knowing, Doing and Being. Also, in the field of education in Australia, Aboriginal scholars are developing and successfully implementing Aboriginal Ways of Knowing into western systems of education. Aboriginal Ways of Knowing such as the 'Aboriginal Eight Ways Pedagogy' (Yunkaporta \& Kirby 2011), Indigenous Ways of Knowing, Being and Doing (Martin 2003; Martin 2008) and programs 
such as 'Young Doctors for Life'(MALPA 2017) are moving beyond non- Aboriginal 'objectifying' and 'dehumanising' approaches (Behrendt 2016; Hogarth 2017) to embedding Aboriginal and Torres Strait Islander knowledges and perspectives into contemporary curricular. These programs, and others like them, are actively engaged in the validation of Indigenous Ways of Knowing to both Indigenous and non-Indigenous teachers and students.

My re-entry into the academy came unexpectedly. Having attended an information session about a new master's degree, I found myself filled with that nervous energy that comes with the excitement and fear of a new adventure. Looking back, I know, Grandmother Bolongaia, that my journey and completion of the Masters of Indigenous Education would not have been possible without the dedication and ongoing support of Professor Michelle Trudgett and Professor Susan Page.

Grandmother Bolongaia, this was a very challenging time in my life. It is not unusual for Indigenous scholars to juggle commitments to family, community, work and study (Fredericks et al. 2011; Trudgett 2009), the unexpected loss of my youngest sister, Dannie, further effected my family and in turn my academic journey. I would not have progressed to be the PhD candidate I am today if not for the environments designed and supported by Professor Michelle Trudgett and Professor Susan Page. This is a true story Grandmother Bolongaia and a story that is not unique. The research of Asmar, page and Radloff (2015), Barney (2016) and Trudgett (2009) illustrates that Indigenous students experience challenges not necessarily experienced by non-Indigenous students,

'there are additional factors that impact the success of Indigenous Australian doctoral students that are dissimilar to those that impact most non-Indigenous doctoral students. Notably, community and family responsibilities can have a tremendous impact on the student, and supervisors must be mindful of such expectations (Trudgett 2014, p.1047).

With this in mind, I am also grateful to Corrinne Sullivan, a proud Wiradjuri scholar, whom I thoroughly enjoyed teaching with and learning from. Even during the first semester while learning the internal systems and protocols, I knew I was supported, and my knowledge and experience valued. To my surprise and pleasure, Corrinne honoured me by attending my graduation, which was something I had not expected due to her own exhaustive commitments. Page and Asmar (2008) identify the value and importance of 
this type of support to Indigenous students. However, they also note a distinct lack of recognition and support for efforts of such teachers, stating:-

'the commitment to supporting Indigenous students comes from the desire to contribute to the emancipation of Indigenous communities. Our research indicates that the work people do in this area continues to be unnoticed and unrewarded, with the personal costs uncounted' (p.116).

Grandmother Bolongaia, since the beginning of the Masters of Indigenous Education, I have met and read so many inspirational Indigenous Women. They have guided, supported and extended my learning and understanding of identity and responsibilities within and outside the academy.

\section{Aboriginal Ways of Knowing Being and Doing in the Academy.}

Dear Grandmother Bolongaia,

It is important to note, that as a consequence of invasion, Indigenous Ways of Knowing, from our old people (like your father, Yarramundi), have been fractured and in some cases lost. This reality has given strength and credit to a non-Aboriginal view that Indigenous Ways of Knowing are 'traditional' ways of living, and an assumption that Indigenous Knowledges are therefore extinct or without merit in contemporary society (Behrendt 1995; Fredericks 2013). But, Grandmother Bolongaia you and I both know that Indigenous Knowledges are and have always been inclusive of past, present and future practices and life experiences of Indigenous People (Watson 2007).

Indigenous scholars such as Karen Martin (2008) have made significant contributions to the recognition, representation and inclusion of Indigenous Ways of Knowing in the academy. Her work titled, "Please knock before you enter: Aboriginal regulation of outsiders and the implications for researchers" (Martin 2008), has been instrumental in advocating an Indigenous perspective to non-Indigenous scholars and has guided my own research into the inclusion of Indigenous Knowledges and Perspectives in Early Education and Care Services. For this reason, I will use this Indigenous Framework of Knowing, Being and Doing (Martin 2008) to share with you the thoughts and strength of Indigenous women who continue to challenge stereotyped assumptions made about Indigenous people in the academy and across society. 


\section{Indigenous Ways of Knowing}

Indigenous peoples view their own Indigenous knowledges from a very different perspective to that of non-Indigenous peoples (Semann, Proud \& Martin 2012). As the very foundation of Indigenous Ways of Knowing are entrenched in the land (Dudgeon et al. 2017; Heiss 2018; Kwaymullina 2017; Watson 2017), the only way to dismantle western based misrepresentations of Indigenous Ways of Knowing is to privilege, if not centre, the voices and experiences of Indigenous Australians in research and education institutions (Martin 2003; Santoro et al. 2011; Semann, Proud \& Martin 2012; Sherwood et al. 2011). Martin (2008) explains that Indigenous Ways of Knowing involve understanding your own connection to Country.

"The core conditions of Ways of Knowing are to know, as fully as it is possible, 'who your People are'; 'where your Country is' and 'how you are related to the Entities'. That is to know your Stories of relatedness, the individual and communal Stories and through this, your identities unfold (p.78)".

Today, Grandmother Bolongaia, it is disheartening to tell you that it is not an uncommon experience for an Aboriginal person's identity and, as a consequence their knowledge to be questioned. Aboriginal identity is overwhelmingly misinterpreted and misunderstood by nonAboriginal people and is often prescribed by those in positions of power and/or influence, such as politicians, educators and the media (Behrendt 2016; Carlson 2016; Heiss 2012). Being fair of skin, like myself, invites unwarranted questions of authenticity from people who fail to understand that being Aboriginal cannot be confined to prescribed notions of appearance, knowledge and/or behaviours. However, Indigenous women from Australia and abroad have stood up in the academy to decolonize the accepted notions of what it is to be an Indigenous person from an Indigenous perspective.

For example, Larissa Behrendt's $(1995,2016)$ work challenges the non-Indigenous views and assumptions which purport that Aboriginal people who live and work in urban spaces are not 'traditional' or 'real Aborigines'. Likewise, Fredericks (2013) states that,

“We don't leave our identities at a petrol station, bus stop, jetty or airport when we enter the city limits. When we live in a city or town, we don't become any less or any more Indigenous. Some of us even belong to the Country where huge cityscapes and towns have been built' (p.1). 
Interpretation of Indigenous identity from non-Indigenous perspectives have created mostly negative stereotypes about what it is to be an Indigenous person (Behrendt 1995; Carlson 2016; Heiss 2012). Contemporary examples of such labelling and racism are prevalent in many of the stories shared by Aboriginal Australian people in a book titled, 'Growing up Aboriginal in Australia' (Heiss 2018). However, a quote from a D'harawal colleague, Shannon Foster (2018), in the book mentioned above, clearly exemplifies the complexities and underlying truths that can be connected to knowing you are Aboriginal.

"This is what I grew up to believe it meant to be Aboriginal: to be Aboriginal meant that you were smart, intelligent, inventive and resilient - just like my dad. I had no idea that I should be ashamed of being Aboriginal and hide it like the family I read about in Sally Morgan's Book, 'My Place'. Where I lived you didn't have to be shamed - you just had to be silent. Just never mention it' (p87).

The Indigenous women mentioned above have provided me with sound evidence to say that, when Indigenous Ways of Knowing are used to interpret Indigenous belonging and identity, stereotypical misrepresentations are excluded and Indigenous people, such as myself become empowered.

\section{Indigenous Ways of Being}

Grandmother Bolongaia, a recently published book (Dudgeon et al. 2017) provides the voices of fifteen Indigenous women all of whom share their own stories of 'Being'. Whilst each story is unique in content and detail, the underlying core of each story revolves around the role that relationships with people and places play in their lives. These include relationships with self, family, community, society and in the case of this particular book, the relationships that these women have to one another as Indigenous academics (Oxenham \& Milroy 2017).

The themes and topics that are presented by these Indigenous women range in diversity from identity, gender, sexuality and Indigenous role models, to storytelling, colonisation and selfreflection. Each chapter in this book (Dudgeon et al. 2017) illustrates three conditions of 'Being', as described by Martin (2008) from a Quandamookah epistemological perspective. According to Martin (2008), the conditions of 'respect', 'responsibility' and 'accountability' enable Indigenous peoples to confirm and retain their relatedness with 'self and the Entities', the 'Entities' meaning all aspects of Country (animals, plants, earth, waterways and sky). 
From this perspective, Ways of Being are not confined by specific acts or experiences; rather it is the 'attitude' in which one shares knowledge, stories and themselves. A quote by Kwaymullina (2017 in the above mentioned book provides an example in which all three conditions of respect, responsibility and accountability are visible.

"what stories can we as women now tell to ourselves and our children that will enable us to value our holistic Indigenous selves? That will equip us to perceive and sustain the connections between people and people, and people and country, which have always been the core of an Indigenous way of being? And that have allowed us to so far overcome the devastation of colonisation so that we can imagine the possibility of a better world for ourselves and for future generations of Indigenous people (p.100)".

This comment respectfully acknowledges Indigenous people as holistic and recognises the value and significance of connections to people and Country. It expresses responsibility to one's self and to Indigenous children in all time frames: - past, present and future.

Additionally, it expresses accountability in the way that it speaks to the strength and abilities of Indigenous people to overcome the effects of colonisation and of providing Indigenous children with a future in which they have the potential to be proud and strong in their Indigenous identities.

Of course, there is more than one way in which to enact our Ways of Being as they have been reframed by the effects of invasion. This point has been clearly articulated by another Aboriginal scholar, Aileen Moreton-Robinson (2000) when she states that,

"Individuals learn to acquire new knowledge in order to act and function in contexts not of their choosing or control within the dominant culture. Indigenous women have had to gather knowledge about white people and use it in order to survive in white Australian society. The accumulation of such knowledge does not mean that we have become assimilated. Instead, what it points to is that Indigenous subjectivity is multiple because of the conditions under which it has been and is shaped" (p.89).

I find strength in this quote, as Moreton-Robinson makes it clear to me that our Ways of Being are not static nor homogenous, they are in fact complex. I am made aware that the diversity of our Ways of Being, are indicative of both the strength and resilience of Indigenous women such as yourself. 


\section{Indigenous Ways of Doing}

Finally, Grandmother Bolongaia, Indigenous Ways of Doing is the third aspect of the Quandamooka epistemological framework identified by Martin (2008). It is reliant on 'knowing' how one is related to Country and the associated entities, as well as 'being' clear on the expectations of respect, responsibility and accountability within that same space. From Martin's (2008) point of view, it is a complex system which involves both the process and the practices of engaging and enacting relatedness to Country with all entities across all paradigms; from physical to spiritual. It necessitates an understanding of Indigenous Ways of Knowing and Being; of all entities to engage and enact with each one in their own relevant and meaningful ways. This undoubtedly requires knowledge of Indigenous stories that explain the relationships and responsibilities of people to a given place.

From this perspective, Indigenous Ways of Doing could be considered as restrictive of Indigenous people whom have been displaced by government policies such as assimilation and protection. For these Indigenous people access to the stories of one's relatedness to Country and the entities are limited at best which in turn severely restricts engagement on Country in the manner that has been prescribed by Martin (2008). Although the Australian social, political and physical landscapes have changed as a result of invasion, practices such as respecting Elders, caring for and connection to Country and responsibility to community are all evidenced in the literature authored by Indigenous scholars (Behrendt 1995; Fredericks 2013) as well as in the lives of Indigenous People. The existence of practices and protocols such as Acknowledgement and Welcome to Country and, the use of Yarning Circles (Bessarab \& Ng'andu 2010) are clear examples of Indigenous Ways of Doing. In mainstream society, and in Indigenous communities across Australia, there are Aboriginal and Torres Strait Islander people actively fulfilling a wide diversity of roles from politicians to artists, and film makers to homemakers.

Because of Indigenous women scholars, Indigenous Ways of Doing are not restricted to nonIndigenous assumptions about Aboriginal art and culture. For me, a Boorooberongal woman of the Darug Nation, the very act of writing and engaging in Indigenist Research is a genuine expression of my Indigenous Ways of Knowing, Being and Doing. While, I am in some ways confined by the western requirements of the $\mathrm{PhD}$ process, I remain ever respectful, responsible and accountable to my Aboriginal ancestors, family and community. 


\section{Conclusion}

Dear Grandmother Bolongaia,

As I conclude this letter to you, I express my gratitude to Aboriginal and Torres Strait

Islander women who have fought for the recognition and inclusion of Indigenous knowledges in western based academic systems and societies. I believe that we have come a long way from the exclusion of Indigenous knowledges and voices to an ever-growing strength and volume. This is evidenced in the increasing presence and achievements of Indigenous women scholars in the very educational institutions that once excluded and belittled us. I acknowledge my contributions to these voices has only been possible because of the choices and actions you, Grandmother Bolongaia, made when you were taken into the Native Institution so many years ago and to the strong brave women who came after you and before me. I hope that my contributions will help to increase the volume and validity of our people's knowledges and culture into the future. Surely, if the work I do today validates, motivates and strengthens the knowledge and journey of our Dharug children in seven generations to come, then I will have walked our Dreaming right way.

Didjurigur Grandmother Bolongaia

One of your many Granddaughters, Michelle xxx

\section{References}

Asmar, C., Page, S. \& Radloff, A. 2015, 'Exploring anomalies in Indigenous student engagement: Findings from a national Australian survey of undergraduates', Higher Education Research \& Development, vol. 34, no. 1, pp. 15-29.

Barney, K. 2016, 'Pathways to postgraduate study for Indigenous Australian students: Enhancing the transition to Higher Degrees by Research'.

Battiste, M. 2005, 'Indigenous knowledge: Foundations for first nations', World Indigenous Nations Higher Education Consortium-WINHEC Journal.

Behrendt, L. 1995, 'Aboriginal urban identity: Preserving the spirit, protecting the traditional in nontraditional settings', Australian Feminist Law Journal, vol. 4, no. 1, pp. 55-61.

Behrendt, L. 2016, Finding Eliza: Power and colonial storytelling, Univ. of Queensland Press.

Bessarab, D. \& Ng'andu, B. 2010, 'Yarning about yarning as a legitimate method in Indigenous research', International Journal of Critical Indigenous Studies, vol. 3, no. 1, pp. 37-50.

Bunda, T. 2018, 'The raced space of learning and teaching', in G. Vass, Maxwell, J., Rudolf, S. \& Gulson, K.N (ed.), The Relationality of Race in Education Research, Routledge, Abingdon, Oxon, pp. 85 - 96.

Carlson, B. 2016, The Politics of Identity: Who Counts as Aboriginal Today?, Aboriginal Studies Press, Canberra ACT. 
Christie, M. 1994, 'Educating bungelene: A case of educational colonialism', History of Educational Review, vol. 23, no. 2, pp. 46-54.

Cruickshank, J. 2008, 'To Exercise a Beneficial Influence over a Man': Marriage, Gender and the Native Institutions in Early Colonial Australia', Evangelists of Empire? Missionaries in Colonial History, no. 18, p. p. 115.

Dudgeon, P., Herbert, J., Milroy, J. \& Oxenham, D. (eds) 2017, Us Women, Our Ways, Our World, Magabala Books, Broome. Western Australia.

Fredericks, B. 2013, "We don't leave our identities at the city limits': Aboriginal and Torres Strait Islander people living in urban localities', Australian Aboriginal Studies, no. 1, p. 4.

Fredericks, B.L., White, N., Bunda, T. \& Baker, J. 2011, 'Demonstrating Indigenous women's educational leadership: Tiddas Showin'Up, Talkin'Up and Puttin'Up!', Journal of Australian Indigenous Issues, vol. 14, no. 1, pp. 3-8.

Heiss, A. 2012, Am I black enough for you?, Random House, Sydney Australia.

Heiss, A. (ed.) 2018, Growing Up Aboriginal in Australia, Black Inc, Victoria Australia.

Hogarth, M. 2017, 'Speaking back to the deficit discourses: a theoretical and methodological approach', The Australian Educational Researcher, vol. 44, no. 1, pp. 21-34.

Kovach, M. 2009, Indigenous methodologies: Characteristics, conversations, and contexts, University of Toronto Press.

Kwaymullina, A. 2017, 'The Creators of the Future: Women, Law and Telling Stories in Country', in P. Dudgeon, J. Herbert, J. Milroy \& D. Oxenham (eds), Us Women, Our Ways. Our World, Magabala Books, Broome. Western Australia, pp. 96-104.

MALPA 2017, MALPA. Closing The Gap, viewed 24/07/2017 2017, $<$ http://www.malpa.org.au/youngdoctors/>.

Martin, K. 2003, 'Ways of knowing, being and doing: A theoretical framework and methods for Indigenous and Indigenist re-search', Journal of Australian Studies, vol. 27, no. 76, pp. 20314.

Martin, K.L. 2008, Please knock before you enter: Aboriginal regulation of outsiders and the implications for researchers, Post Pressed Brisbane.

Moreton-Robinson, A. 2000, Talkin'up to the white woman: Aboriginal women and feminism, Univ. of Queensland Press.

Moreton-Robinson, A. 2009, 'Imagining the good indigenous citizen: Race war and the pathology of patriarchal white sovereignty', Cultural studies review, vol. 15, no. 2, p. 61.

Morgan, G. 2006, 'Memory and Marginalisation-Aboriginality and Education in the Assimilation Era', Australian journal of education, vol. 50, no. 1, pp. 40-9.

Oxenham, D. \& Milroy, J. 2017, 'Introduction', in P. Dudgeon, J. Herbert, J. Milroy \& D. Oxenham (eds), Us Women, Our Ways, Our World, Magabala Books, Broome. Western Australia, pp. 11-7.

Page, S. \& Asmar, C. 2008, 'Beneath the teaching iceberg: Exposing the hidden support dimensions of Indigenous academic work', The Australian Journal of Indigenous Education, vol. 37, no. S1, pp. 109-17.

Page, S., Trudgett, M. \& Sullivan, C. 2017, 'Past, present and future: Acknowledging Indigenous Achievement and Aspiration in Higher Education.', HERDSA Review of Higher Education, vol. 4, pp. 29-51.

Parbury, N. 2011, 'A history of Aboriginal education', in R. Craven (ed.), Teaching Aboriginal Studies. A Practical Resource For Primary And Secondary Teaching, 2 edn, Allen and Unwin, Crows Nest NSW, pp. 132-52.

Santoro, N., Reid, J.-A., Crawford, L. \& Simpson, L. 2011, 'Teaching Indigenous children: Listening to and learning from Indigenous teachers', Australian Journal of Teacher Education (Online), vol. 36, no. 10, p. 65. 
Semann, A., Proud, D. \& Martin, K. 2012, 'Only Seeing Colour? Identity, pedagogy and ways of knowing.', in A. Fleet, C. Patterson \& J. Robertson (eds), Conversations: Behind early childhood pedagogical documentation, Pademelon Press, Castle Hill, NSW, pp. 245-57.

Sherwood, J., Keech, S., Keenan, T. \& Kelly, B. 2011, 'Indigenous studies: teaching and learning together', in N. Purdie, G. Milgate \& H.R. Bell (eds), Two Way Teaching and Learning. Toward culturally reflective and relevant education., ACER Press, Victoria, Australia., pp. 189-202.

Smith, L.T. 2012, Decolonising Methodologies. Research and Indigenous Peoples, 2nd edn, Zed Books Ltd, London.

Sydney Gazette 1819, vol. 17, no 2, Sydney. Australia, pp. 2-3, viewed 10/04/2018, $<$ https://trove.nla.gov.au/newspaper/page/494181>.

Torpey, J. 2013, 'Deepening Histories of Place', Leanne Tobin. Don't Deny Me My Heritage, $<$ http://dhrg.uws.edu.au/at-the-heart-of-it/leanne-tobin-3/>.

Trudgett, M. 2009, 'Build it and they will come: Building the capacity of Indigenous units in universities to provide better support for Indigenous Australian postgraduate students', The Australian Journal of Indigenous Education, vol. 38, no. 1, pp. 9-18.

Trudgett, M. 2014, 'Supervision provided to Indigenous Australian doctoral students: a black and white issue', Higher Education Research \& Development, vol. 33, no. 5, pp. 1035-48.

Watson, I. 2007, 'Settled and unsettled spaces: Are we free to roam', Sovereign subjects: Indigenous sovereignty matters, pp. 15-32.

Watson, I. 2017, 'Standing Our Ground and Telling the One True Story', in P. Dudgeon, J. Herbert, J. Milroy \& D. Oxenham (eds), Us Women, Our Ways, Our World, Magabala Books, Broome. Western Australia, pp. $129-42$.

Wilkie, M. 1997, Bringing them home: Report of the national inquiry into the separation of Aboriginal and Torres Strait Islander children from their families, Human Rights and Equal Opportunity Commission.

Yunkaporta, T. \& Kirby, M. 2011, 'Yarning Up Indigenous pedagogies: A dialogue about eight Aboriginal ways of learning', in N. Purdie, G. Milgate \& H.R. Bell (eds), Two Way Teaching an dLearning. Toward culturally reflective and relevant education, ACER Press, Victoria, Australia, pp. 205-13. 